\title{
Ethnobotanical Survey of Medicinal Plants Used By the Traditional Medical Healers in the Villages of Bérégadougou and Fabédougou (Cascades Region, Burkina Faso).
}

\author{
Sourabie $^{1}$ T.S., Kinda ${ }^{1}$ D., Yaro ${ }^{1}$ B. And J.B. Nikiema ${ }^{2}$ \\ ${ }^{I}$ : Département Médecine Pharmacopée Traditionnelles/Pharmacie, Institut de Recherche/Sciences de la Santé \\ (MEPHATRA/PH-IRSS), 03 BP 7192 Ouagadougou 03, Burkina Faso (West Africa). \\ 2: Unité de Formation et de Recherche/Sciences de la Santé (UFR/SDS), Université de Ouagadougou, Burkina \\ Faso (West Africa).
}

\begin{abstract}
:
Bacground:An ethnobotanical study carried out in two localities of Cascades Region (Bérégadougou and Fabédougou) and aimed to collect data on medicinal plants (MP) from the traditional medical practitioners and to identify the medicinal plants used for treating ailments.

Methods :Questionnaires were given to the informants represented by a group of traditional medical faith healers within the framework of open-ended conversations. Field trips have been also necessary to perform the data collection.

Results:The survey recorded 95 plant species belonging to 60 plant families, 80 genera used in the treatment of diseases in the 2 villages. The most dominant families were represented by Caesalpiniaceae (9,47 \%), followed by Rubiaceae (6,31\%), Combretaceae (5,26 \%), Apocynaceae, Asteraceae and Solanaceae (3,15\% for the three families). The leaves represented $55 \%$ as predominant part of medicinal recipes, followed by the roots (35\%) and the others (flowers, stem or barks) less than $10 \%$. Concerning the traditional method of drug preparation, the decoction was the most commonly utilized. Moreover, the plants inventoried in the study area showed two interesting profiles: solely medicinal profile (leaves), dietary profile as edible food plants (fruits); some of them presented the two combined properties.
\end{abstract}

Conclusion:The field trips carried out in the two villages and around revealed a great richness of the study area in term of medicinal plants species. And in addition to their knowledge in medicinal plants domain, the faith healers met in Bérégadougou and Fabédougou possess also solid knowledge in the healthcare of plenty pathologies existing in the two visited villages.

KEYWORDS:ethnomedicinal, Bérégadougou and Fabédougou, medicinal plants, traditional medical practitioner.

\section{INTRODUCTION}

The use of natural resources such as minerals, animals and plants for healing ailments is a practice dating since at the origin of Humanity. In the particular case of medicinal plants, which constitute the fundamental basis of traditional medicine in many African countries, ethnobotany and ethnopharmacognosy play a great role in the knowledge of pharmacological potentialities of these plants.

Indeed, according to the World Health Organization (WHO) about $80 \%$ of the population around the world depends on traditional medicine, mostly herbal remedies, for their primary health care needs [1, 2]. African continent have a long history with the use of plants and in some African countries up to $90 \%$ of population rely on medicinal plants (MP) as source of drugs [3]. A medicinal plant is any plant, which in one or more of its organs contains active ingredients that can be used for therapeutic purposes or contains foundation compounds that can be used for the synthesis of useful drugs [4].In Burkina Faso, as in the other developing countries of West African region, Traditional Medicine occupies an important place in the system of health care. Medicinal plants (MP) constitute the fundamental substrate used in the traditional healthcare system. That MP is characterized by combination of knowledge and practices of all the communities living through the country. Therefore it integrated in our culture, our customs and our social practice and then it is transmitted orally since several centuries [5]. 
In the face of the fullness of traditional medical practice by more than $70 \%$ of the population [6], the governmental authorities of the country, at the end of years 1990 voted laws destined to recognize traditional medicine. By this political act, institution of Traditional Medicine became a reality in Burkina Faso; thus it coexists near the conventional medicine. The two medicines (traditional and conventional) constitute the base of the healthcare system in Burkina Faso. In order to specify the interest of the sanitary authorities for traditional medicine, it has been created within the ministry of health, a special department in charge of traditional medicine and all the medical traditional practitioners. This service is called "Department of Traditional Medicine and Pharmacopeia" and is administrated by a pharmacist.

In the same objective, the researchers of the department of medicine, traditional pharmacopeia and pharmacy (MEPHATRA/PH) from the Research Institute of Health Service (IRSS) undertake ethnobotanical and ethnopharmacognostical studies in different areas of the country in direction of traditional medical faith healers. Indeed, many of the plants used in the folk medicine in Burkina Faso have never been investigated for their chemical composition and pharmacological activities. It is therefore important for the researchers to study these plants to substantiate the traditional medical knowledge. For this, several missions of researcher teams have been carried out through different zones from country in the hope to valorize scientifically all the data of medicine and traditional pharmacopeia in Burkina Faso. This was the aim of our mission in the villages of Bérégadougou and Fabédougou. And there, the activities consisted to exchange with the medical faith healers on divers aspects touching Traditional Medicine in these two areas: organization of the faith healers, their capacity in term of medicinal plants knowledge, the pathologies circulating in the areas, their reaction regarding the progressive disappearance of some plants which become more and more rare. Fields trip have been also carried out in order to make a large inventory on medicinal plants met in the investigated zone.

\section{Materials and methods Study area and ethnology}

The study was carried out in Bérégadougou and Fabédougou, villages located in the department of Bérégadougou (administrative center of the department). The village of Bérégadougou is about $15 \mathrm{~km}$ far from Banfora (regional capital). The study area was in great part out of the village, including a vast vegetative zone with plenty useful trees as food plants, medicinal plants, etc. The village (Bérégadougou) is limited in eastern by a big valley containing an important gallery forest following the course of a stream with abundant vegetation. It is also limited in the west by fields of sugar cane and by a mountain in the northern part.

Fabédougou is a locality $7 \mathrm{~km}$ far from Bérégadougou; it is located upstairs near the hills surrounding the village. The climate within the two villages is typically tropical to sub-tropical, the average annual rainfall, temperature and humidity being $1000 \mathrm{~mm}, 27^{\circ} \mathrm{C}$ and $80 \%$, respectively. The former inhabitants of the two villages (Bérégadougou and Fabédougou) belong to the ethnic group of Turka, an ethnic group originated from that area. Beside this native group of population, other ethnics coming from different areas of the country and out of Burkina Faso inhabit with the native in perfect collaboration.

This is observed particularly in Bérégadougou due to the development of industrial culture of sugar cane. In term of activities, the inhabitants of the village are in their great majority agricultural producers. They cultivate millet, maize, groundnuts, and sorghum during the rainy season. In addition of supplies cultures, culture of cotton has been introduced and it becomes more and more predominant.

\section{Data collection}

To perform this data collection the help of traditional medical practitioners was needed. They are faith healers with a great competence to practice traditional medicine [7]. They were identified after inquiries taken next to the elders of the tribe but equally on the base of their personal notoriety. A total of 32 faith healers were interviewed ( 24 healers from Bérégadougou and 8 from Fabédougou) amongst whom some were literate. Their ages range from 30 to 65 years with more of them in the elder side of the range. No female was present among all the informants interviewed. This is due to the fact that exercise of traditional medicine is generally reserved to the men; but there are some aged women who are in possession of medicinal plants knowledge.

The study was performed during the last week of December 2006 and the traditional medical faith healers were interviewed through questionnaires and open-ended conversations. During the meeting with the informants (traditional medical faith healers), the discussions aimed to appreciate the degree of knowledge of the traditional practitioners on medicinal plants, the plant parts used, diseases treated by the plants, the mode of usage and administration. The unknown specimens collected during the field trips investigation were destined for identification in the MEPHATRA/PH Department and then after authenticated. These unknown specimens will give a large overview on the cure potency of the plants according to the medical traditional practitioners met in the two villages. 


\section{Organization of the faith healers}

\section{RESULTS}

During the survey period a total of 52 healers coming from the 2 areas have been interviewed. Contrarily to the traditional healers of Fabédougou, those of Bérégadougou were gathered together in an association. The authorities of the administrative department officially recognize all the members of this traditional healer association. This association is opened to any traditional medical practitioner who desires to participate; the integration to the group as member is conditioned by the payment of inscription fees. Meetings are often organized within the group of healers and this constitutes a framework of exchange and discussion about the problems met in the domain of traditional medical knowledge. The domination of men in the practice of traditional medicine in the 2 visited zones was very characteristic. Indeed, 50 healers among the 52 interviewed $(96,15 \%)$ were men between 35 and 45 years; the oldest of the group met in Fabédougou was 71 years old. A little number of them was less than 25 years old and among these, the youngest was 22 years. The women were weakly represented amongst the faith healers $(03,84 \%)$ questioned during this survey; since according to certain authors $[1 ; 7 ; 8]$ they (women) seem to have less knowledge than men in the domain of traditional medicine.

Their presence (women) as traditional faith healer in the ethnic group of Turka has always existed but not so important in term of representation of traditional faith healers. The explanations given by the old persons questioned about this is simply due to the customs and the cultural tradition. Tables $1 \& 2$ give an overview on the repartition of the healers in the investigated areas.

Table 1: An overview of the traditional medical faith healers interviewed

\begin{tabular}{cccc}
\hline Villages & Number of medical & \multicolumn{2}{c}{ Sex } \\
traditional faith healers & Males & Females \\
\hline Bérégadougou & 44 & 42 & 02 \\
Fabédougou & 08 & 08 & 00 \\
\hline
\end{tabular}

The results above showed the total predominance of men $(96,15 \%$ against 3,85\% for women) in the folk system of medicine in the two visited localities.

Table 2: Repartition of the traditional healers gathered in function to the age range.

\begin{tabular}{cccc}
\hline Age range & Number of healers & Males & Females \\
\hline $20-30$ & 07 & 07 & 00 \\
$30-45$ & 13 & 00 & 00 \\
$45-60$ & 15 & 14 & 01 \\
$60-70$ & 05 & 04 & 01 \\
$\geq 70$ & 02 & 02 & 00 \\
\hline
\end{tabular}

\section{Level of knowledge of the healers}

The traditional medical healers interacted during the study period showed different instruction levels. A few numbers of them (less than 10 faith healers) have never been to school; they expressed only in local language. This category of practitioner was met in the group of 60-70 years and over. All the exchanges about their knowledge on traditional medical practice necessitated the help of a translator.Those of the medical faith healers who went to school characterized the second category but not so far (less 3 years of scholarship); they left school for long time and then became illiterate. They constitute the most important group of healers met in the 2 areas; they are represented by the age range of 30-45 and 45-60 years old. The presence of a translator was not imperative during the interviews. The last group was formed by the age range of 20-30 years old (table 2). They can be considered as literate because most of them did at least four to five years of scholarship. This group is responsible to the organization of the activities of their "Association of Traditional Medical Practitioners of Bérégadougou". They play a great role within the association like registration of member names, writing the local name of plants or part plants used, etc. 


\section{Medicinal potential of the plants listed}

The vegetal biodiversity of the study area was characterized by the existence of a rich flora comprising a various medicinal plants. A total of about 95 medicinal plant species coming from more 80 genera and 60 families have been inventoried. These plants are used by the traditional faith healers to treat a great number of diseases circulating particularly malaria, dysentery, gastroenteritis, skin ailments, jaundice and inflammatory diseases, etc.

And among the useful plants inventoried, the most dominant plant family was represented by Caesalpiniaceae $(9,47 \%)$, Rubiaceae, $(6,31 \%)$, Combretaceae $(5,26 \%)$ followed by Apocynaceae, Asteraceae and Solanaceae $(3,15 \%)$. The representation of other species showing medicinal interest was less than $2 \%$ in term of space distribution. These curative plant parts were constituted by trees $(27 \%)$, shrubs $(18 \%)$, climbers $(5 \%)$ and particularly the herbs $(53 \%)$. The plants species used by the medical healers of the visited villages (Bérégadougou \& Fabédougou) showed 2 origins:

\section{Medicinal plants of wild origin}

Such of these reported medicinal plant species were specifically collected during the field walks; they were distributed in the natural vegetation and the density of diverse species was high. List of the medicinal plants species harvested from the wild is given below (Table 3).

Table 3: List of wild medicinal plants species met in the study area

\begin{tabular}{|c|c|c|c|c|}
\hline No & Species & Family & Part used & Medicinal Uses \\
\hline 01 & Acacia nilotica & Caesalpiniaceae & Fruit & Antibacterial \\
\hline 02 & Afzlia africana & Caesalpiniaceae & Leaf, bark & Febrifuge, constipation \\
\hline 03 & Ageratum conyzoides $L$. & Asteraceae & Leaf & Cut, wound \\
\hline 04 & Alstonia scholaris $(L) \mathrm{Br}$ & Apocynaceae & Leaf, bark & Headache, stomach \\
\hline 05 & Begonia roxburghii (Miq) DC & Begoniaceae & Leaf & Indigestion \\
\hline 06 & Borreria verticillata (L) GFW Mey & Rubiaceae & Leaf & Antibacterial \\
\hline 07 & Bridelia ferruginea & Euphorbiaceae & Leaf, roots, & Anemia \\
\hline 08 & Calotropis procera L. & Asclepiadaceae & Roots & Sicklemia \\
\hline 09 & Carissa edulis (Forssk.) & Apocynaceae & Roots & Abdominal pain \\
\hline 10 & Combretum micranthum & Combretaceae & Leaf & Diuretic \\
\hline 11 & Combretum glutinosum Perr & Combretaceae & Leaf & $\begin{array}{l}\text { Antibact, } \\
\text { hypotension }\end{array}$ \\
\hline 12 & Chenopodium ambrosioides $L$. & Chenopodiaceae & Leaf & Toothache \\
\hline 13 & Crossopteryx febrifuga & Rubiaceae & Leaf & Fever, malaria \\
\hline 14 & Crotolaria pallida Ait. & Fabaceae & Roots & Bodyache \\
\hline 15 & Dioscorea alata $L$ & Dioscoreaceae & Tuber & Indigestion \\
\hline 16 & Entada africana Guill. et Per. & Mimosaceae & Leaf, roots & Inflammation \\
\hline 17 & Ficus platyphylla Del. & Moraceae & Leaf & Antibacterial \\
\hline 18 & Khaya senegalensis & Meliaceae & Bark & Anti-inflammatory \\
\hline 19 & Lippia chevalieri & Verbenaceae & Leaf & Fever, cholagogue \\
\hline 20 & Maytenus senegalensis (Lam) & Celasteraceae & Leaf, roots & Laxative, dysentery \\
\hline 21 & Mitragyna inermis & Rubiaceae & Leaf & Antidiabete \\
\hline 22 & Mitracarpus scaber Zucc & Rubiaceae & Leaf & Skin treatment \\
\hline 23 & Ocimum gratissimum & Lamiceae & Leaf & Antibacterial, \\
\hline 24 & Parkia biglobosa & Mimosaceae & Stem bark & Anti-infl. ,antibact \\
\hline 25 & Paullinia pinnata $L$. & Sapindaceae & Roots, leaves & Erectile dysfunction \\
\hline 26 & Phyllanthus amarus Schumach. & Euphorbiaceae & Roots, leaves & Antiviral $\mathrm{C}$ hepatitis \\
\hline 27 & Piliostgma reticulatum (DC) Hochst & Fabaceae & Fruit (clove) & Food for animals \\
\hline 28 & Polygonum perfoliatum $L$. & Polygonaceae & Leaf & Indigestion \\
\hline 29 & Sarcocephalus latifolius & Rubiaceae & Roots, leaf & Spasmolytic, antibacterial \\
\hline 30 & Securidaca longepedunculata & Polygalaceae & Roots & Snake bite \\
\hline 31 & Solanum nigrum L. & Solanaceae & Leaf & Sedative, antispasmodic \\
\hline 32 & Strophanthus gratus & Apocynaceae & Seeds & Cardiotonic \\
\hline 33 & Terminalia macroptera et Guill. Perr & Combretaceae & Leaf, Roots & Cough, snake bite \\
\hline 34 & Trichilia emetica Vahl & Meliaceae & Roots & Antibacterial, dermatitis \\
\hline 35 & Vernonia cirenea $(L)$ & Asteraceae & Leaf & Indigestion \\
\hline 36 & Vernonia colorata $L$. & Asteraceae & Leaf & Antipyretic \\
\hline
\end{tabular}




\begin{tabular}{|c|c|c|c|c|}
\hline 37 & Xanthoxylum xanthoxyloides & Rutaceae & Roots & Sickle disease \\
\hline 38 & Opilia celtidifolia Guill. et Perr. & Opiliaceae & Leaf, roots & Malaria, jaundice, dermatitis \\
\hline 39 & Cochlospermum tinctorium A. Rich. & Cochlospermaceae & Roots, leaf & Malaria, jaundice \\
\hline 40 & Piliostigma thonningii & Caesalpiniaceae & Leaf, bark & Malaria, digestive disorders \\
\hline 41 & Trichilia emetica Vahl & Meliaceae & Root bark, leaf & $\begin{array}{l}\text { Dermatitis, } \\
\text { haemorrhoids, }\end{array}$ \\
\hline 42 & Erythrina senegalensis DC & Papilionaceae & $\begin{array}{l}\text { Leaf, trunk- } \\
\text { bark }\end{array}$ & Antibacterial, analgesic \\
\hline 43 & Saba senegalensis & Apocynaceae & $\begin{array}{l}\text { Latex, feaf, } \\
\text { bark }\end{array}$ & Stop vomiting, dysentery \\
\hline 44 & Annona senegalensis & Annonaceae & $\begin{array}{l}\text { Latex, } \\
\text { bark }\end{array}$ & Antidiarrhoea \\
\hline 45 & Commiphora africana & Burseraceae & Roots & Jaundice \\
\hline 46 & Burkea africana & Caesalpiniaceae & Bark & Cough, stomac ache \\
\hline 47 & Lannea acida & Anacardiaceae & Leaf & Dermatitis, mycosis \\
\hline 48 & Crotalaria obovata & Papilionaceae & Leaf & Jaundice \\
\hline 49 & Calotropis procera & Asclépiadaceae & Root, root bark & $\begin{array}{l}\text { Anti } \\
\text { dysentery }\end{array}$ \\
\hline 50 & Combretum micranthum & Combretaceae & Leaf, bark & Jaundice, \\
\hline 51 & Terminalia avicennoides & Combretaceae & Leaf & Colic, abdominal pain \\
\hline 52 & Guiera senegalensis & Combretaceae & Leaf & Cough, malaria \\
\hline 53 & Securidaca longepedunculata & Polygalaceae & Root & Hepatoprotective, fever \\
\hline 54 & Xanthoxylum xanthoxyloides & Rutaceae & Root & Sickle disease \\
\hline 55 & Piliostigma thonningii & Caesalpiniaceae & Leaf, stem bark & Antibacterial, worm \\
\hline 56 & Vitellaria paradoxa & Sapotaceae & Fruit & Dietary, cosmetic, \\
\hline 57 & Sclerocarya birrea & Anacardiaceae & Bark, leaf & Diabete, alaria, indigestion \\
\hline 58 & Nauclea latifolia Sm. & Rubiaceae & Leaf, root bark & $\begin{array}{l}\text { Malaria, } \\
\text { antibacterial }\end{array}$ \\
\hline 59 & Detarium senegalensis & Caesalpiniaceae & Fruit & vitamine $\mathrm{C}$ \\
\hline
\end{tabular}

\section{A remarkable presence of domestic medicinal plants species}

The presence of domestic plants species among the investigated species was significant. These domesticated plant species growth in the villages, near the houses or surroundings. A great number of them were harvested from the wild study area. Some of those domesticated plants presenting medical interest have been cultivated exclusively for curative purposes. Their cultivation is due to many factors such as the rarity of collected plant samples, the progressive disappearance of interesting medicinal species, the bush fire, etc. without forgetting the destructor role of men on the environment. Tables $4 \& 5$ below showed the list of the domestic plants species inventoried and those cultivated solely for their medicinal uses

Table 4: list of the home medicinal plant species inventoried

\begin{tabular}{cccc}
\hline Species & Family & Habit & Plant part used \\
\hline Aframomum melegueta & Zingiberaceae & Herb & Rhizome \\
Alium sativum $L$. & Alliaceae & Herb & clove of garlic \\
Aloe vera $($ L) Burm.f & Papaveraceae & Herb & Leaf \\
Argemone mexicana $L$ & Meliaceae & Herb & Leaf, root, stem \\
Azadirachta indica $L$. & Balanitaceae & Tree & Leaf \\
Balanites aegyptiaca & Sapindaceae & Tree & Fruit \\
Blighia sapida & Arecaceae & Tree & Fruit \\
Borasus aethiopum Mart. & Solanaceae & Herb & Fruit, flowers \\
Capsicum annum $L$. & Caricaceae & Tree & Fruit \\
Carica papaya $L$. & & & Fruit
\end{tabular}




Citrus aurantium L.
Citrus limonum
Cymbopogon citratus
Elaeis guinensis Jacq.
Eucalyptus globules
Euphorbia hirta
Jatropha curcas
Khaya senegalensis
Lantana camara $L$.
Mangifera indica $L$.
Maytenus senegalensis
Moringa oleifera
Nicotiana tabacum L.
Parkia biglobosa
Psidium guajava
Senna alata $(L)$ Roxb.
Senna occidentalis
Senna siamea
Senna tora
Solanum nigrum L.
Tamarindus indica $L$
Vernonia colorata
Vitellaria paradoxa
Ximenia americana $L$.

Rutaceae
Rutaceae
Poaceae
Arecaceae
Myrtaceae
Euphorbiaceae
Euphorbiaceae
Meliaceae
Verbenaceae
Anacardiaceae
Celasteraceae
Moringaceae
Solanaceae
Meliaceae
Myrtaceae
Caesalpiniaceae
Caesalpiniaceae
Caesalpiniaceae
Caesalpiniaceae
Solanaceae
Fabaceae
Asteraceae
Sapotaceae
Olacaceae

\begin{tabular}{c} 
Tree \\
Tree \\
Herb \\
Tree \\
Tree \\
Herb \\
Sub shrub \\
Tree \\
Herb \\
Tree \\
Tree \\
Tree \\
Herb \\
Tree \\
Shrub \\
Tree \\
Tree \\
Tree \\
Herb \\
Shrub \\
Tree \\
Herb \\
Tree \\
Shrub \\
\hline
\end{tabular}

The trees presented the dominant growth form $(58,88 \%)$ among all the domestic medicinal plants inventoried, followed by the herbs $(32,35 \%)$ and others as climbers and shrubs $(8,77 \%)$.

Table 5: List of some medicinal plant species cultivated for their curative purposes

\begin{tabular}{ccc}
\hline Botanical name & Family & Medical uses \\
\hline Argemone mexicana $L$ & Papaveraceae & Treatment (leaves) jaundice, malaria fever \\
Azadirachta indica $L$. & Meliaceae & Curation (leaves) of malaria, inflammatory pains \\
Carica papaya $L$. & Caricaceae & The leaves treat jaundice illness \\
Euphorbia hirta $L$. & Euphorbiaceae & Treatment (hole plant) of dysentery, asthma, \\
Jatropha curcas & Euphorbiaceae & NP* \\
Moringa oleifera & Moringaceae & Treatment (leaves) of vitamin deficit \\
Psidium guajava & Myrtaceae & Treatment (leaves) of diarrhea, dysentery \\
Senna alata $(L)$ Roxb. & Caesalpiniaceae & Leaves used against constipation, malaria fever \\
Vernonia colorata & Asteraceae & Treatment (leaves) of fever, malaria \\
Nauclea latifolia $S m$ & Rubiaceae & Roots and leaves for jaundice, malaria and colic treatment \\
Ricinus communis $L$. & Euphorbiaceae & NP* \\
\hline
\end{tabular}

NP*: not précised

\section{Part of edible plants}

About thirty six (36) medicinal plants among the 95 which have been collected in the study area showed an edible property $(37,89 \%)$. They were originated either from wild or domestic plants. The edible parts were mainly represented by the fruits $(17,89 \%)$, the leaves $(13,88 \%)$, the bulb $(5,55 \%)$ and the seeds $(2,77 \%)$. The contribution of the only edible fraction (of the medicinal plants species) in the health care was significantly weak if compared to the non-edible medicinal plants.Indeed, a few number of them showed a pharmacological activity. Six (06) medicinal plant species exhibited a medical interest by the edible fraction: Adansonia digitata (Bombacaceae), Balanites aegyptiaca (Balanitaceae), Carica papaya (Caricaceae), Hibiscus sabdariffa (Malvaceae), Parkia biglobosa (Mimosaceae), Tamarindus indica (Caesalpiniaceae). The edible parts of medicinal plant species showing pharmacological activities are resumed on table 6 below. 
Table 6: List of edible part plants showing a pharmacological activity

\begin{tabular}{lll}
\hline \multicolumn{1}{c}{ Species } & Family & \multicolumn{1}{c}{ Medical uses } \\
\hline Adansonia digitata & Bombaccaceae & Pulp of fruit has anti-diarrhoeal property \\
Balanites aegyptiaca & Balanitaceae & Pulp of fruit used as anthelmintic \\
Carica papaya & Caricaceae & Hole fruit (green) treats jaundice \\
Hibiscus sabdariffa & Malvaceae & Flowers possess antibacterial property \\
Parkia biglobosa & Mimosaceae & Seeds of fruit treat hypertension \\
Tamarindus indica & Caesalpiniaceae & Clove used against constipation \\
\hline
\end{tabular}

\section{DISCUSSION}

The ethnobotanical investigations led on medicinal plants in the study areas revealed the extraordinary richness of the vegetal biodiversity in term of medicinal plant species concerning the visited localities. The results obtained showed that medicinal drugs originated from plants are still widely used by the population of the two villages. The data gathered with the informants during the discussions or during the field trips indicate the high level of knowledge of the traditional medical healers in Beregadougou and Fabedougou. The investigations showed also that the exercise of traditional medical is practiced only by men over than $80 \%$ in the ethnic group Turka. The reason of the weak presence of women in this domain according to the old healers questioned is to keep the medical plants knowledge within (inside) the male members of the family. For the female children, they are supposed to disclose the family secrets on medical plants knowledge in case of marriage with a stranger.As highlighted by many authors [5,9,10,11,12], the place of edible plants among the medicinal plant species is far to be negligible in the traditional pharmacopeia of Burkina Faso. Effectively, the results of the study showed that $37,89 \%$ of the whole medicinal plant species inventoried in the study area exhibited an edible power. And it has been found that some edible part plants within the medicinal plants listed were also capable to cure other illness at the same effectiveness like the former drug. This double property (medicinal and edible power) of such kinds of plants offers to the populations many alternatives: either using the curative part plants for the healthcare of pathologies circulating or taking the edible part to cover dietary needs. The example of the followed medicinal edible plants frequently used in the Cascades Region is very illustrative (Table 7): Annona senegalensis (Annonaceae), Adansonia digitata (Bombacaceae), Carica papaya (Caricaceae), Parkia biglobosa (Mimosaceae) and Moringa oleifera (Moringaceae).

Table 7: examples of medicinal and edible potential exhibited by some medicinal plants species collected in the study area (Beregadougou \&Fabedougou).

\begin{tabular}{|c|c|c|c|}
\hline & & \multicolumn{2}{|c|}{ Medicinal uses } \\
\hline Species & Family & $\begin{array}{l}\text { Edible parts } \\
\end{array}$ & Non edible parts \\
\hline Adansonia digitata & Bombacaceae & $\begin{array}{l}\text { Pulp of fruit : analgesic, anti- } \\
\text { diarrhea, anti-inflammatory } \\
\text { Leaves: presence of calcium, iron, } \\
\text { anti-inflammatory }\end{array}$ & $\begin{array}{l}\text { Stem bark: antipyretic } \\
\text { Seeds: products an anti- } \\
\text { inflammatory oil }\end{array}$ \\
\hline Annona senegalensis & Annonaceae & Fruit used against intestinal parasites & Root bark: treatment of snakebite \\
\hline Carica papaya & Caricaceae & Green fruit: treatment of jaundice & Leaves: treatment of malaria fever \\
\hline Parkia biglobosa & Mimosaceae & Pulp of fruit rich in vitamins & Seeds: used as anti-hypertension \\
\hline Moringa oleifera & Moringaceae & $\begin{array}{l}\text { Leaves: presence of multivitamins } \\
\text { (A, B, D, E, etc); antimicrobial. }\end{array}$ & Seeds: oil rich in fatty acids \\
\hline
\end{tabular}

\section{CONCLUSION}

This study showed that a great variety of medicinal plants are used by the traditional medical healers in Beregadougou and Fabedougou for treating diverse sickness. The discussions held with the faith healers on their medical practices equally revealed that the knowledge of the use of plants for the healthcare has been with the people for several generations without being recorded.Moreover, our results showed the important role played by the edible plants in the traditional pharmacopeia in our country. This constitutes a considerable advantage for the populations who can benefit either from the edible plant parts to improve their dietary problems (like lack of vitamins, vegetables or vegetal proteins, etc.) or to exploit the curative power of these edible plant parts for their healthcare. Finally, the local population particularly the youth should be educated and also encouraged to learn more the traditional medicinal knowledge in order to preserve it from being lost with the old generation. 


\section{ACKNOWLEDGEMENTS}

We thank the traditional medical faith healers in Beregadougou and Fabedougou who served as informants for this work in the study areas. We are particularly grateful towards Mr. Seydou SOMBIE, team leader (Chief) of the Traditional Medical Practitioners Association in Beregadougou and his members for their great contribution in the realization of this work. They accepted to lead us in the bush during all the steps of the field trips for the reconnaissance (inventory) of medicinal plant species without any condition.

\section{REFERENCES}

[1]. David J. imbo (2010)- An ethnobotanical urvey of medicinal plants in Babungo, Northwest Region, Cameroon. Journal of Ethnobiology and Ethnomedicine, 6:8;1-8.

[2]. Muthu C., Ayyanar M., Raja N., Ignacimuthu S. (2006)- Medicinal plants used by traditional healers in Kancheepuram of Tamil Nadu, India. J. Ethnobio. Ethnomed., 2:43.

[3]. Hostettmann K., Marston A., Ndjoko K., Wolfender J-L. (2000)- The potential of African Medicinal Plants as a source of Dugs. Current Organic Chemistry, 4:, 973-1010.

[4]. Sofowara A. (1993)- Medicinal plants and traditional medicine in Africa. Spectrum books limited Ibadan.

[5]. T.S. Sourabié, N. Somé, O. Bognonou, Y. Ouattara, J.B. Ouédraogo (2012)- Ethnobotanical and ethnopharmacognostical survey on medicinal plants of Malon village and surrounding in the Cascades Region (Burkina Faso). International Organization of Scientific Rsearch. Under press (accepted on Jan 2013; ID-26026).

[6]. Institut National de la Statistique et de la Démographie (INSD), 2007. Analyse des résultats de l'enquête sur les conditions de vie des ménages en 2007. Ouagadougou: INSD, Octobre 2007.

[7]. Adiaratou Togola, Drissa Diallo, Seydou Dembélé, Hilde Barsett and Berit Smestad Paulsen (2005)Ethnopharmacological survey of different uses of seven medicinal plants from Mali, (West Africa) in the regions Doila, Kolokani and Siby. Journal of Ethnobiology and Ethnomedicine, 1:7, 1-9.

[8]. Fisseha Mesfin, Sebsebe Demissew and Tilahun Teklehaymanot (2009)- An ethnobotanical study of medicinal plants in Wonago Woreda, SNNPR, Ethiopia. Journal of Ethnobiology and Ethnomedicine, 5:28.

[9]. Bélem et al. (2006). Potentialités des galeries forestières de la réserve de biosphère de la Mare aux Hippopotames à l'ouest du Burkina Faso: cas des plantes médicinales. 11ème Colloque International sur le développement, Environnement et Santé, Bamako, 12-16 juin.

[10]. Sourabié T.S. (2006). Enquêtes ethnobotaniques et ethnopharmacognosiques dans la zone de la mare aux hippopotames de Bala. Rapport de mission du Projet MAB du 16 au 23 mars; 11 p.

[11]. Millogo/Koné (2008)- Etude de la phytochimie et des activités biologiques d'extraits de Parkia biglobosa (Jacq.) Bent (Mimosaceae). Thèse de Doctorat d'Etat, UFR/SVT, Université de Ouagadougou, 169 pages.

[12]. Nacoulma, G.O., (1996). Plantes médicinales et pratiques traditionnelles au Burkina Faso : Cas du plateau central. Thèse es Sciences Naturelles. Université de Ouagadougou, Institut des Sciences Naturelles. 605 